\title{
RELN Gene
}

National Cancer Institute

\section{Source}

National Cancer Institute. RELN Gene. NCI Thesaurus. Code C102799.

This gene is involved in both proteolysis and signaling. 